\title{
Dossier Évolution et créationnisme Intelligent Design Theory
}

\author{
Michael Ruse \\ Professor of Philosophy, Director of the Program in the History and Philosophy of Science, Department of Philosophy, \\ Florida State University, Tallahassee, Florida, 32306, USA
}

Intelligent Design Theory is the claim that some features of organisms are so complex - "irreducibly complex" - that they could not possibly have come into existence through normal causes, through processes of blind law, and hence demand the supposition of a designer who thought them up and put them into place (Ruse, 2005; Forrest and Gross, 2004). The key work is that of Lehigh University biochemist Michael Behe (1996), who argues in Darwin's Black Box that things like the clotting process of blood are so intricate that they cannot possibly have evolved, and certainly not evolved through Charles Darwin's mechanism of natural selection ${ }^{1}$. There must have been an intelligence behind such a process. Behe and his fellows try deliberately not to say what this intelligence might be, but truly no one thinks that it is an extraterrestrial. No one thinks that there is some graduate student on Andromeda who is running life on Earth as an experiment and who intervenes in the course of nature every now and then to see what will happen. The intelligence is the God of Christianity. Intelligent Designers are much given to quoting the first verse of the Gospel according to Saint John - "In the beginning was the word, and the word was with God, and the word was God."

I need hardly say that for regular scientists, Intelligent Design Theory is anathema. They argue that it simply cannot be supported by the evidence. A favorite example of Behe to illustrate the notion of irreducible complexity is

\footnotetext{
Corresponding author: mruse@mailer.fsu.edu

1 Voir, dans ce numéro, le texte d'introduction au dossier «Évolution et créationnisme »: Anne-Françoise Schmid, «La théorie de l'évolution face au créationnisme ", ainsi que l'article de Kathryn Tabb, "La téléologie de Darwin ». Par ailleurs, un compte rendu de l'ouvrage de M. Ruse, The EvolutionCreation Struggle figure dans la rubrique « Lectures - Ouvrages en débat ».
}

that of a mousetrap. It has five parts - spring, base, and so forth-and each part is essential. Remove one part and the trap fails. Behe argues that this mechanism cannot have come about naturally, but must have been designed and been put together by an intelligence. But regular scientists point out that in fact the trap can be made to work with fewer than five parts - remove the base for example and it still functions (Ruse, 2003). Likewise with something like blood clotting. In humans, it is indeed a very complex mechanism, with something like twenty-eight different processes in a row. (For this reason, it is known as the blood clotting "cascade".) But there exist in other animals far more simple cascades that function very well, and significantly the processes in humans have the marks of having been adapted from one more basic process and then extended through time in search of greater efficiency.

The point is that Behe (and his fellows) quite misunderstand the way in which evolution works. You cannot just look at something functioning today and reason that it must always have functioned in this precise manner or not at all. Life is put together in bits and pieces by a process that the French Nobel Prize Jacob Monod winner called a bricolage. You start with one process, then extend it, then modify it, and so forth, until you reach the state of things today (Miller, 1999). The even greater point is that Behe (and his fellows) violate the very rules of modern science. You simply cannot appeal to forces outside nature in the quest for understanding. It is often said, truly, that a scientist is a methodological atheist. This does not mean that a scientist cannot believe in the existence of God. Some of the greatest evolutionists in the twentieth century were sincere Christians, the Russian-born American population geneticist Theodosius Dobzhansky and the English theoretical biologist Ronald A. Fisher, to name but two (Ruse, 1999). The point is that in the pursuit 
of science one puts one's faith to one side, and one works with the conviction that law-bound causal processes can be found. For the religious believer, in fact, the belief that such processes exist is part of the respect for God, rather than a denial.

Why does Intelligent Design Theory exist and why do its proponents refuse to see its problems? The answer is part theological and part political. Theologically, it is not just that Intelligent Design theorists want to support the existence of God - we have just seen that regular evolutionists can do this too if they want - but that they see normal science, evolutionary biology in particular, as having a positive force for atheism, whatever its proponents may say. They point to the ways in which biologists like the English writer Richard Dawkins $(2003,2006)$ and philosophers like the American thinker Daniel Dennett (1995) actively trumpet their non-belief in God's existence and how they do link evolution and atheism. Even if the God of Evolution does exist, argue the Intelligent Design supporters, He is much more remote than the conventional God of Christianity. Politically, the reason for Intelligent Design Theory is that the United States constitution separates Church and State, and today this is interpreted as meaning that there can be no teaching of religion in state supported schools, especially no teaching of religion in the biology classes of state supported schools. Intelligent Design Theory is a Trojan horse, intended to get religion into the schools by stealth, pretending to be science even though truly it is not.

In other words, Intelligent Design Theory is only the latest salvo in the ongoing fight between American biblical literalists and students of the life sciences, a fight that has been going on at least since the publication of Charles Darwin's On the Origin of Species in 1859 and that has been marked by such events as the Scopes trial in 1925, when a young school teacher in Tennessee was prosecuted for (and found guilty of) teaching that humans are descended from monkeys (Larson, 1997). This does not mean that there have been no changes through time. The classic Creationist book of the twentieth century was Genesis Flood (1961) by biblical scholar John Whitcomb and hydraulic engineer Henry M. Morris (who died recently). This argued that the world is only six thousand years old and that all kinds of organisms were made miraculously in the first week. (There was always scope for change after the Flood, paradoxically more rapidly than conventional evolutionists would allow.) Most Intelligent Design theorists argue for a conventionally aged universe of fifteen billion years old, and some (including Michael Behe) agree that generally the picture was one of evolution. It is just that every now and then there were major interventions by God, something denied by conventional evolutionists. But what connects all kind of creationists, including the Intelligent Design supporters (leading me to call them "Creationism lite") is that they see the main threat of evolution lying in the general godless universe it supposedly supports, up to and very much including a lack of moral standards. The éminence grise of the Intelligent Design movement is retired University of California at Berkeley law professor Phillip Johnson, and he harps on continually about the decline in moral standards today, something in major part he lays at the feet of evolutionists (Johnson, 1991 and 1995).

As a committed evolutionist, an enthusiast for Charles Darwin's mechanism of natural selection, I dislike and deplore Intelligent Design Theory. But I do not underestimate its attraction, especially in the United States of America. This is a fight for the long haul, and those of us who think that science is the true testament to the fact that we are little lower than the angels and not just modified monkeys must be prepared to battle for many years to come.

\section{References}

Behe, M., 1996. Darwin's Black Box: The Biochemical Challenge to Evolution, New York, London, Toronto and Sydney, Free Press.

Darwin, C., 1859. On the Origin of Species, London, John Murray.

Dawkins, R., 2003. A Devil's Chaplain: Reflections on Hope, Lies, Science and Love, Boston and New York, Houghton Mifflin.

Dawkins, R., 2006. The God Delusion, Boston, Houghton Mifflin.

Dennett, D.C., 1995. Darwin's Dangerous Idea, New York, Simon and Schuster.

Forrest, B., Gross, P.R., 2004. Creationism's Trojan Horse: The Wedge of Intelligent Design, Oxford, Oxford University Press.

Johnson, P.E., 1991. Darwin on Trial, Washington (DC), Regnery Gateway.

Jonhson, P.E., 1995. Reason in the Balance: The Case Against Naturalism in Science, Law and Education, Downers Grove (Ill.), InterVarsity Press.

Larson, E.J., 1997. Summer for the Gods: The Scopes Trial and America's Continuing Debate over Science and Religion, New York, Basic Books.

Miller, K., 1999. Finding Darwin's God, New York, Harper and Row.

Ruse, M., 1999. Mystery of Mysteries: Is Evolution a Social Construction?, Cambridge (Mass.), Harvard University Press.

Ruse, M., 2003. Darwin and Design: Does Evolution have a Purpose?, Cambridge (Mass.), Harvard University Press.

Ruse, M., 2005. The Evolution-Creation Struggle, Cambridge (Mass.), Harvard University Press.

Whitcomb, J.C., Morris., H.M., 1961. The Genesis Flood: The Biblical Record and its Scientific Implications, Philadelphia, Presbyterian and Reformed Publishing Company. 